\title{
Model Alternatif Parenting Islami pada Lembaga Pendidikan Anak Usia Dini
}

\author{
Masganti Sit ${ }^{\natural} \bowtie$, Raisah Armayanti Nasution ${ }^{2}$ \\ Pendidikan Islam Anak Usia Dini, Universitas Islam Negeri Sumatera Utara, Indonesia(1) \\ DOI: $\underline{10.31004 / \text { obsesi.v6i2.1149 }}$
}

\begin{abstract}
Abstrak
Orang tua mempunyai banyak peran, diantaranya yaitu sebagai pendidik dan pembina sikap pada anak. Namun tidak semua orang tua memahami materi pembinaan sikap yang dibutuhkan anak pada usia dini. Tujuan dari penelitian ini yaitu mengembangkan model alternatif parenting Islami di lembaga PAUD yang valid dan efektif. Metode penelitian yang digunakan yaitu penelitian pengembangan yang menghasilkan produk berbentuk buku panduan. Penelitian dilakukan selama 6 (enam) bulan. Uji coba produk dilakukan di RA Milda Wiranti, RA An Nida dan TK IT Bunayya 7. Penelitian ini telah menghasilkan produk berbentuk buku panduan sebagai model alternatif parenting Islami pada lembaga PAUD. Dari hasil penelitian, buku panduan terbukti valid sehingga dapat disosialisasikan pada 20 sekolah PAUD/ sederajat yang berada di wilayah kabupaten Deli Serdang dan kota Medan. Buku panduan model alternatif parenting Islami dinilai sangat dibutuhkan orang tua, siswa ataupun pihak lembaga PAUD, khususnya lembaga PAUD berbasis Islam.
\end{abstract}

Kata Kunci: karakter islami; parenting islami; pendidikan anak usia dini

\begin{abstract}
Parents have many roles, including as educators and builders of attitudes towards children. However, not all parents understand the material for developing the attitudes needed by children at an early age. The purpose of this research is to develop a valid and effective alternative model of Islamic parenting in PAUD institutions. The research method used is development research that produces a product in the form of a guidebook. The study was conducted for 6 (six) months. Product trials were conducted at RA Milda Wiranti, RA An Nida and TK IT Bunayya 7. This research has resulted in a product in the form of a guidebook as an alternative model for Islamic parenting in PAUD institutions. From the research results, the guidebook is proven valid so that it can be disseminated to 20 PAUD / equivalent schools in the Deli Serdang district and Medan city. The guidebook for the alternative model of Islamic parenting is considered very much needed by parents, students or PAUD institutions, especially Islamic-based PAUD institutions.
\end{abstract}

Keywords: early childhood education programs; islamic character; islamic parenting

Copyright (c) 2021 Masganti Sit, Raisah Armayanti Nasution

$\triangle$ Corresponding author :

Email Address : masganti@uinsu.ac.id (Medan, Sumatera Utara, Indonesia)

Received 14 February 2021, Accepted 9 March 2021, Published 7 August 2021 


\section{PENDAHULUAN}

Undang-Undang RI Nomor 32 tahun 2009 Tentang Perlindungan Anak menegaskan bahwa anak sejak lahir sampai usia 18 tahun merupakan tanggung jawab orang tua. Orang tua berkewajiban membiayai pendidikan dan kehidupan anak. Oleh sebab itu meskipun orang tua mendelegasikan anaknya ke lembaga pendidikan, mereka tetap bertanggung jawab terhadap pendidikan anaknya di rumah. Namun, faktanya tidak semua orang tua memiliki kemampuan dalam mendidik dan mengasuh anak dengan baik. Oleh sebab itu, diperlukan sebuah edukasi terkait dengan pengasuhan anak (parenting) oleh orang tua. Sesungguhnya, orang tua tidak dibenarkan mengalihkan tugas pengasuhan anaknya kepada orang lain. Pengasuhan (parenting) memerlukan sejumlah kemampuan interpersonal dan mempunyai tuntutan emosional yang besar, namun sangat sedikit pendidikan formal yang mengajarkan atau melatih orang tua untuk melakukan tugas ini (Santrock, 2009) .

Sejumlah penelitian terkait parenting islami telah dilakukan, misalnya penelitian Annisa (2016); Kenkre \& Young (2013) menunjukkan bahwa kebutuhan emosional dalam pengasuhan anak usia dini sangatlah besar, dan perbaikan perilaku seorang ibu adalah kunci untuk menuai sikap dan emosi positif pada diri anak. Robbiyah et al. (2018) menginformasikan bahwa kebutuhan yang diberikan melalui pola asuh ibu akan memberikan kesempatan pada anak usia dini untuk menunjukkan bahwa dirinya adalah sebagian dari orang-orang yang berada di sekitarnya. Cathy \& Bennett (2013) juga telah melakukan penelitian yang menyimpulkan bahwa secara sistematis program parenting berbasis kelompok dapat meningkatkan pengasuhan. Penelitian ini juga menemukan perubahan sikap yang signifikan pada orangtua dalam mendidik anaknya. Grindal (2016) melaporkan bahwa program parenting education yang dilakukan sebulan sekali dalam bentuk kunjungan rumah dapat meningkatkan pengetahuan orang tua dalam mendidik anak. Berbagai temuan ini mendukung teori yang menyatakan program parenting dapat meningkatkan pengetahuan dan keterampilan orang tua mendidik anak serta meningkatkan kesejahteraan anak (Miller \& Sambell, 2003).

Namun penelitian-penelitian yang sudah dilakukan sebagaimana diungkap di atas belum secara detail mengkaji potret model parenting Islami di lembaga pendidikan anak usia dini, sebab masih terbatas pada mengungkapkan kondisi yang telah ada. Penelitian lainnya belum menawarkan alternatif pada kegiatan parenting yang telah berlangsung di tempat penelitiannya. Oleh karenanya diperlukan sebuah studi yang bukan hanya membahas kegiatan parenting Islami di pendidikan anak usia dini Indonesia tetapi juga memberikan solusi berupa model alternatif parenting Islami yang secara khusus didesain untuk lembaga pendidikan anak usia dini.

Dengan memperhatikan keterbatasan terhadap literatur yang ada, penelitian ini dilakukan untuk menjawab pertanyaan bagaimana model parenting Islami pada lembaga pendidikan anak usia dini di Indonesia? Pertanyaan tersebut dijawab melalui penelitian pengembangan yang menghasilkan sebuah produk berupa buku parenting Islami untuk anak usia dini yang dapat dijadikan sebagai alternatif panduan bagi orang tua siswa maupun guru di lembaga pendidikan anak usia dini. Dengan harapan bahwa artikel ini dapat berkontribusi dalam memperkaya khazanah keislaman khususnya terkait model parenting Islami di lembaga pendidikan anak usia dini. Kebaruan model ini terletak pada partisipasi orang tua dalam kegiatan parenting dari mulai memilih materi, menjadi narasumber materi yang disusun, bermain peran sebagai orang tua dan anak, dan evaluasi pemahaman orang tua terhadap materi yang dibahas.

\section{METODOLOGI}

Penelitian ini menggunakan metode penelitian dan pengembangan (Research and Development) yang telah terlaksana selama 6 (enam) bulan, mulai bulan April sampai dengan bulan Oktober tahun 2019. Produk yang dihasilkan dalam penelitian ini adalah model alternatif parenting Islami pada lembaga pendidikan anak usia dini. Model penelitian dan 
pengembangan yang digunakan, yaitu model Borg and Gall dalam (Muji, 2014; Sugiyono, 2017) yang terdiri dari sepuluh kegiatan, yaitu: 1) studi pendahuluan; 2) perencanaan penelitian; 3) pengembangan produk awal; 4) uji coba lapangan awal; 5) revisi hasil uji coba awal; 6) uji lapangan lebih luas; 7) revisi hasil uji lapangan; 8) uji kelayakan; 9) revisi hasil uji kelayakan; dan 10) diseminasi dan sosialisasi produk akhir. Prosedur pengembangan tersebut disajikan pada Gambar 1.

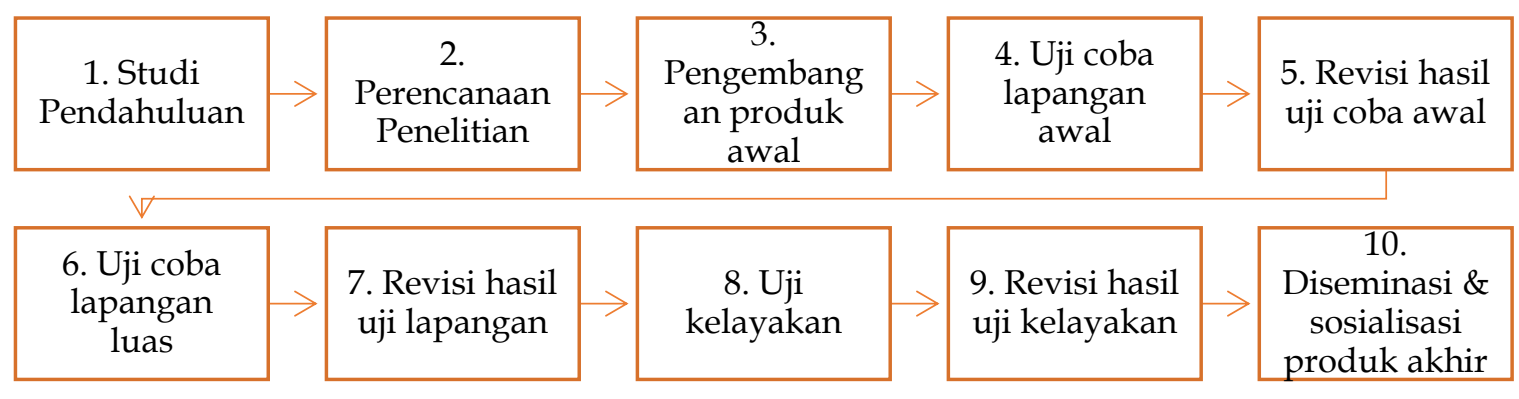

\section{Gambar 1. Prosedur Penelitian dan Pengembangan}

Sumber penelitian ini adalah 1 (satu) orang ahli psikologi, 1 (satu) orang ahli desain grafis, dan 1 (satu) orang ahli bahasa yang menguji validitas modul yang disusun peneliti sebelum digunakan pada subjek penelitian. Subjek penelitian ini berjumlah 42 orang yang terdiri dari: 6 (enam) orang tua siswa di RA Milda Wiranti, 6 (enam) orang tua siswa di RA An Nida, dan 27 orang tua siswa dari TKIT Bunayya 7. Tidak semua orang tua siswa dijadikan sebagai subjek penelitian karena orang tua tersebut harus memenuhi beberapa kriteria sebagai subjek penelitian, yaitu: (1) bersedia mengikuti kegiatan parenting dari awal hingga selesai; (2) mampu membaca bermakna; (3) aktif dalam kegiatan parenting yang diadakan pihak sekolah; dan (4) beragama Islam karena materi parenting berbasis Islam. Instrumen pengumpulan data yang digunakan angket, pedoman validasi modul, modul parenting, observasi, dan tes. Analisis data menggunakan teknik analisis data kualitatif dan kuantitatif. Analisis kualitatif menggunakan model Miles \& Huberman, sedangkan analisis kuantitatif menggunakan rumus persentase $(\mathrm{P})$ sebagai berikut:

Keterangan :

$$
\mathbf{P}=\frac{f}{n} \times \mathbf{1 0 0} \% \text { (Hasibuan et al., 2021) }
$$

P: Angka Persentase

$\mathrm{f}$ : Jumlah anak yang mengalami perubahan

$\mathrm{n}$ : Jumlah seluruh anak

\section{HASIL DAN PEMBAHASAN}

Hasil studi pendahuluan pelaksanaan Parenting Islami pada Lembaga PendidikanAnak Usia Dini sebelum penelitian

Berdasarkan wawancara dengan orang tua murid tentang pelaksanaan Parenting Islami di Lembaga PAUD diperoleh informasi bahwa sudah ada kegiatan pertemuan orang tua dengan pihak sekolah dalam hal melibatkan orang tua dalam kegiatan sekolah seperti kegiatan PHBI, manasik haji, rekreasi, dan family gathering. Namun kegiatan tersebut masih terbatas pada penetapan waktu, pendanaan, dan kehadiran orang tua dalam kegiatan yang dilaksanakan. Belum ada kurikulum atau materi yang disusun yang berkaitan dengan cara mendidik anak seperti yang diusulkan peneliti melalui angket kepada orang tua. Para orang tua menanggapi positif tentang ada buku kegiatan Parenting Islami yang dapat digunakan sekolah dalam pertemuan dengan orang tua. 


\section{Materi Parenting Islami yang Dibutuhkan Orang Tua pada Lembaga PAUD}

Sebelum melakukan penyusunan Modul Panduan Orang Tua Model Parenting Islami di lembaga PAUD, peneliti memberikan angket untuk mengetahui materi yang dibutuhkan orang tua pada Modul yang akan disusun dengan memberikan 100 materi alternatif. Angket tersebut diberikan kepada 14 orang tua dari RA Milda Wiranti dan RA An Nida secara acak. Hasil pilihan orang tua terhadap materi parenting Islami yang ditawarkan kemudian direkapitulasi sebagaimana hasilnya pada tabel 1.

Tabel 1. Materi Parenting Islami yang Dibutuhkan Orang Tua di Lembaga PAUD

\begin{tabular}{|c|c|c|c|}
\hline No & Materi & $\begin{array}{l}\text { Jumlah } \\
\text { Pemilih }\end{array}$ & Persentase \\
\hline 1. & Pengertian Parenting Islami & 14 & $100 \%$ \\
\hline 2. & Kewajiban Mendidik Anak dalam Islam & 14 & $100 \%$ \\
\hline 3. & Tujuan Parenting Islami & 14 & $100 \%$ \\
\hline 4. & Metode Parenting Islami & 11 & $78 \%$ \\
\hline 5. & Bedoa untuk anak ketika masih dalam sulbi & 11 & $78 \%$ \\
\hline 6. & Bedoa ketika anak dalam kandungan & 11 & $78 \%$ \\
\hline 7. & Zikir untuk keselamatan anak & 11 & $78 \%$ \\
\hline 8. & Mengazankan anak & 11 & $78 \%$ \\
\hline 9. & Mentahnik bayi & 11 & $78 \%$ \\
\hline 10. & Membayarkan zakat fitrah anak & 12 & $85 \%$ \\
\hline 11. & Mengaqiqahkan anak & 13 & $93 \%$ \\
\hline 12. & Memberi nama yang baik & 11 & $78 \%$ \\
\hline 13. & Mencukur bayi pada hari ketujuh & 12 & $85 \%$ \\
\hline 14. & Menyusui dan menjamin nafkah anak & 12 & $85 \%$ \\
\hline 15. & Mempercepat shalat ketika anak menagis & 12 & $85 \%$ \\
\hline 16. & Memanggil anak dengan panggilan yang baik & 13 & $93 \%$ \\
\hline 17. & Mengajak shalat berjamaan & 14 & $100 \%$ \\
\hline 18. & Mengajarkan kalimat tauhid & 13 & $93 \%$ \\
\hline 19. & Memperhatikan penampilan anak & 13 & $93 \%$ \\
\hline 20. & Menggendong dan mengajak anak naik kenderaan & 13 & $93 \%$ \\
\hline 21. & Menjaga anak & 12 & $85 \%$ \\
\hline 22. & Mengajarkan anak etika berpakaian & 14 & $100 \%$ \\
\hline 23. & Tersenyum kepada anak & 14 & $100 \%$ \\
\hline 24. & Bercengkerama dengan anak & 14 & $100 \%$ \\
\hline 25. & Memberi hadiah, mendoakan, dan mengusap kepala anak & 14 & $100 \%$ \\
\hline 26. & Menanamkan kejujuran kepada anak & 14 & $100 \%$ \\
\hline 27. & Memberi kesempatan bermain pada anak & 14 & $100 \%$ \\
\hline 28. & Menasehati anak & 14 & $100 \%$ \\
\hline 29. & Berkata lemah lembut kepada anak & 14 & $100 \%$ \\
\hline 30. & Menghargai mainan anak & 14 & $100 \%$ \\
\hline 31. & Jangan mencela anak & 14 & $100 \%$ \\
\hline 32. & Mengajarkan akhlak mulia & 14 & $100 \%$ \\
\hline 33. & Mendoakan anak & 14 & $100 \%$ \\
\hline 34. & Mengajarkan anak amanah & 14 & $100 \%$ \\
\hline 35. & Meluruskan kekeliruan anak & 14 & $100 \%$ \\
\hline 36. & Mengajarkan etika makan & 14 & $100 \%$ \\
\hline 37. & Berlaku adil pada anak & 14 & $100 \%$ \\
\hline 38. & Melerai perkelahian anak & 14 & $100 \%$ \\
\hline 39. & Menggali potensi anak & 14 & $100 \%$ \\
\hline 40. & Mengatur waktu bermain anak & 14 & $100 \%$ \\
\hline 41. & Mengajarkan azan & 14 & $100 \%$ \\
\hline 42. & Mengajarkan shalat & 14 & $100 \%$ \\
\hline 43. & Melatih keberanian anak & 14 & $100 \%$ \\
\hline 44. & Melatih kepemimpinan anak & 14 & $100 \%$ \\
\hline 45. & Memberi anak hadiah dan pujian & 14 & $100 \%$ \\
\hline 46. & Menjaga kesehatan anak & 14 & $100 \%$ \\
\hline 47. & Menghibur anak & 14 & $100 \%$ \\
\hline
\end{tabular}


Tabel 1 menunjukkan bahwa diperoleh rata-rata responden memilih 47 dari 100 materi dengan persentase pilihan antara 11-14 orang setara dengan $78-100 \%$. Jumlah pemilih $\leq 10$ orang untuk satu materi tidak disertakan dalam pengembangan modul Parenting Islami di Lembaga Pendidikan Anak Usia Dini. Oleh sebab itu, buku parenting Islami yang dikembangkan pada penelitian ini hanya membahas 47 materi pada tabel 1 .

\section{Langkah-langkah Penyusunan Panduan Orang Tua Model Parenting Islami}

Langkah kegiatan studi pendahuluan, dan perencanaan penelitian telah dijabarkan, maka pada bagian ini dijabarkan mengenai draft produk yang dikembangkan yaitu model alternatif parenting Islami di lembaga PAUD. Draft produk dikembangkan dalam bentuk buku. Pada buku tersebut terdapat 47 buah materi (tabel 1) mengenai parenting Islami untuk anak usia dini. Semua materi tersebut dijabarkan satu per satu dengan beberapa sub bahasan sebagai berikut: (1) capaian pembelajaran; (2) materi pokok yang bersumber dari Alquran dan hadits; (3) uraian materi; (4) dialog orang tua dan anak dalam bentuk teks dialog; (5) ilustrasi gambar yang disertai teks seperti komik; (6) tugas orang tua: (7) tes formatif untuk anak; dan (8) cara membuat lembar pengamatan proses parenting Islami. Contoh ilustrasi materi yang ada pada produk ini disajikan pada Gambar 2.

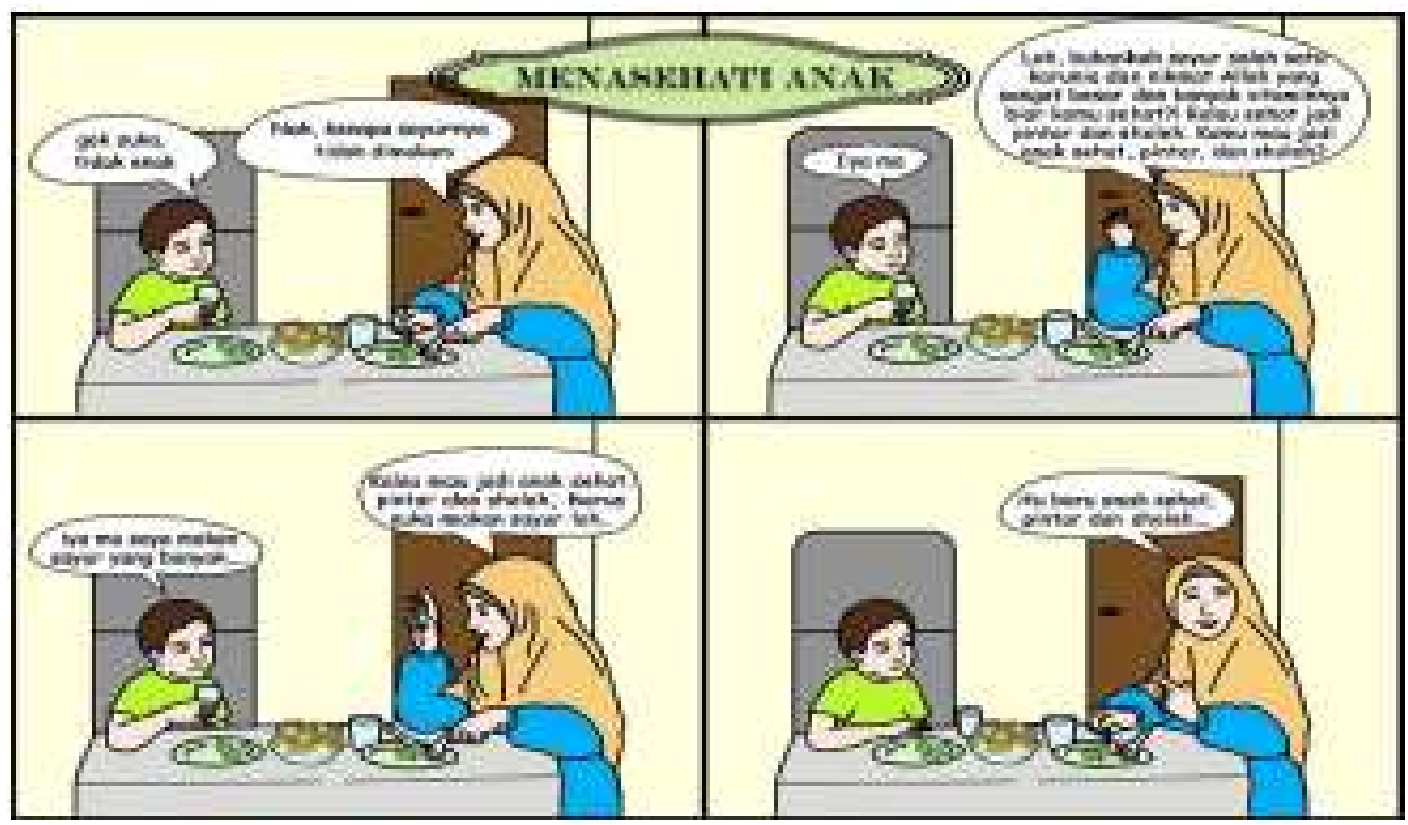

\section{Gambar 2. Ilustrasi Materi Pada Model Parenting Islami di Lembaga PAUD}

Gambar 2 merupakan salah satu contoh ilustrasi materi yang disajikan pada buku panduan orang tua mengenai model parenting islami di lembaga PAUD, dan masih ada 46 buah gambar lainnya yang mengilustrasikan masing-masing materi.

\section{Validasi produk berdasarkan beberapa ahli}

Setelah modul Parenting Islami disusun dilakukan validasi oleh ahli psikologi, ahli desain grafis, dan ahli bahasa. Validator ahli tersebut kemudian memberikan penilaian untuk mengetahui kelayakan produk menggunakan lembar penilaian yang diadaptasi dari penilaian modul yang diajukan BSNP. Modul dinilai layak jika mendapat nilai rata $\geq 3,00$. Mesikpun pada validasi I penilai telah memberikan nilai rata-rata antara 3,00-3,200 tetapi karena ada item-item yang mendapatkan nilai di bawah 3,00 dan ada perbaikan dari penilai dari modul yang sudah disusun, maka peneliti melakukan revisi modul dan melakukan uji validitas ahli sekali lagi untuk menghasilkan modul yang lebih baik. Hasil dari uji validasi ahli disajikan pada Tabel 2. 
Tabel 2. Hasil Uji Validasi

\begin{tabular}{cccc}
\hline Validator ahli & \multicolumn{2}{c}{ Nilai Rata-rata } & \multirow{2}{*}{ Keterangan } \\
\cline { 2 - 3 } & Validasi I & Validasi II & \\
\hline Psikologi & 3,20 & 3,70 & Valid \\
Desain Grafis & 3,00 & 3,30 & Valid \\
Bahasa & 3,00 & 3,80 & Valid \\
\hline Nilai Rata-rata & 3,06 & 3,60 & Valid \\
\hline
\end{tabular}

\section{Pelaksanaan dan Revisi Modul Parenting Islami pada Uji Coba Lapangan Awal}

Modul Parenting Islami yang telah valid menurut ahli diujicobakan secara terbatas pada 6 (enam) orang tua di RA Milda Wiranti selama 6 (enam) hari dengan model ceramah, diskusi, tanya jawab, dan ditutup dengan tes. Dalam pelaksanaan kegiatan, peneliti memulai dengan memberikan pretes, penyampaian materi, diskusi kasus, tanya jawab, dan diakhiri dengan posttes. Uji coba lapangan awal menggunakan 6 (enam) yang diambil secara acak dari modul yang telah disusun.

Hasil evaluasi tentang nilai pengetahuan, sikap, dan keterampilan peserta serta partisipasi orang tua dalam kegiatan Parenting Islami di RA Milda Wiranti dapat dilihat pada Gambar 3.

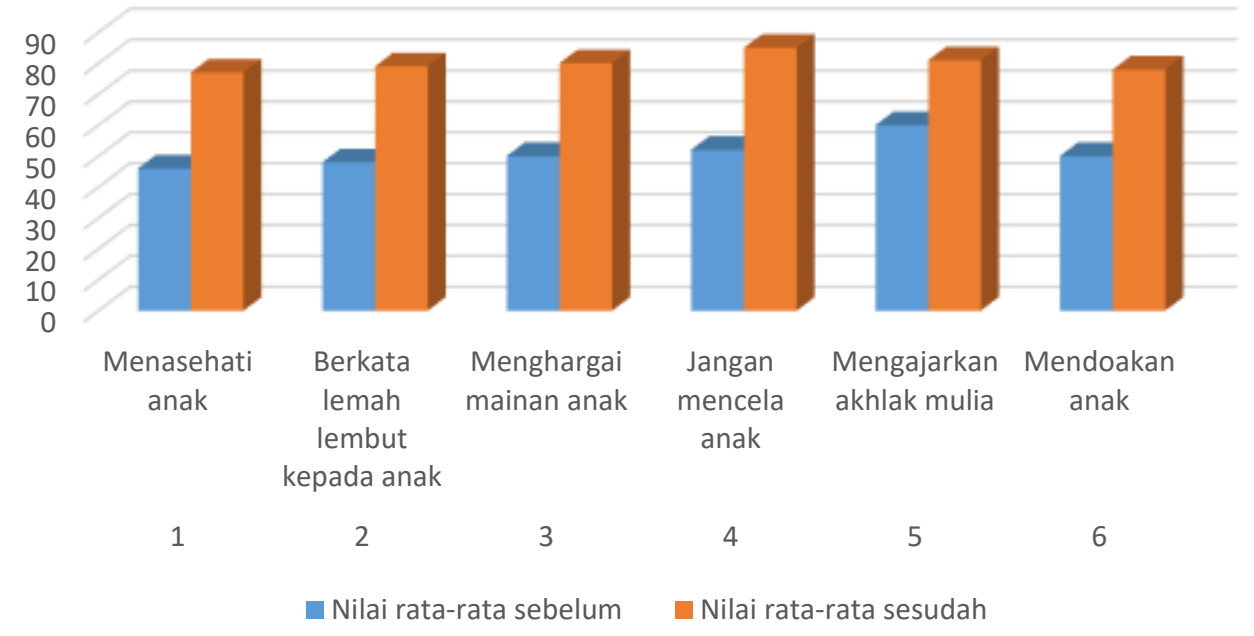

Gambar 3. Peningkatan Nilai Rata-rata Pre tes dan Post tes Orang Tua di RA Milda Wiranti

Hasil pengamatan terhadap partisipasi orang tua dalam kegiatan parenting di RA Milda Wiranti dapat dilihat pada Gambar 4. Rata-rata partisipasi kemudian diakumulasikan dan dihitung rata-rata akhirnya. Dari hasil perhitungan rata-rata akhir partisipasi orang tua diperoleh nilai 4,22 berkategori baik.

Evaluasi kegiatan dilakukan dengan membandingkan nilai sebelum dan sesudah buku Panduan Orang Tua Model Parenting Islami pada Lembaga PAUD. Ujicoba di RA Milda Wiranti menunjukkan ada perbedaan nilai rata-rata antara sebelum dan sesudah kegiatan pembelajaran sebesar 29 poin, dimana nilai rata-rata sebelum pembelajaran 51 menjadi 80 setelah pembelajaran. Hasil uji statistik juga menunjukkan bahwa terjadi perbedaan nilai ratarata yang signifikan yaitu $t_{\text {hitung }} 16,743$ dari $t_{\text {tabel }}$ sebesar 4,032 pada taraf kepercayaan $95 \%$ dengan tingkat kesalahan $5 \%$.

Meskipun tahapan uji coba lapangan ini telah menunjukkan signifikansi modul untuk meningkatkan pengetahuan, sikap, dan keterampilan orang pada materi-materi yang telah dibahas, namun modul masih memiliki kelemahan yaitu pada uji keterampilan orang tua. Di dalam modul masih menggunakan tes tertulis untuk menguji keterampilan orang tua mendidik anaknya sesuai petunjuk modul. Peneliti melakukan perbaikan berdasarkan 
wawancara dengan semua peserta yang menyarankan untuk bermain peran sesuai gambar yang terdapat dalam modul. Berdasarkan saran peserta, peneliti menambahkan kegiatan bermain peran di dalam modul.

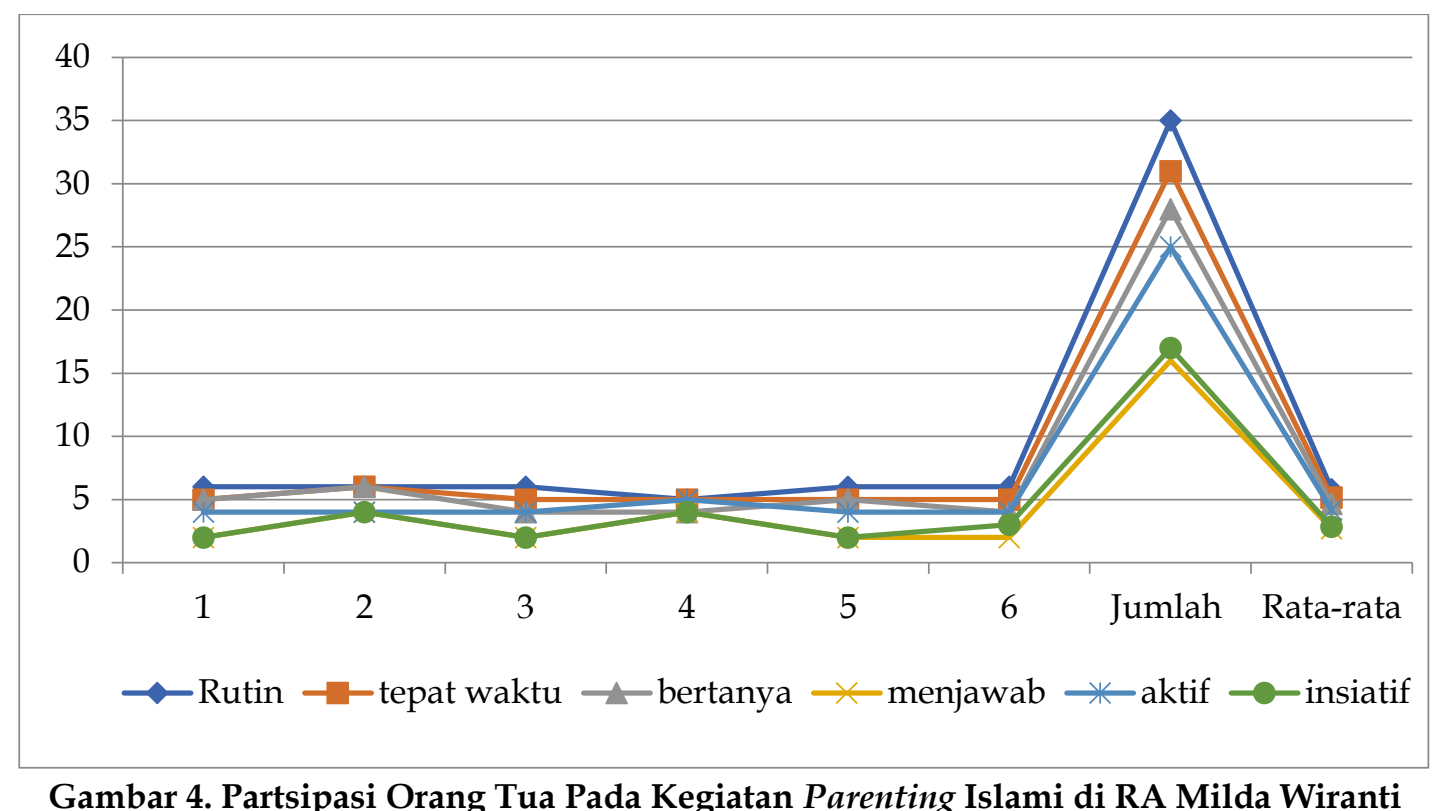

Gambar 4. Partsipasi Orang Tua Pada Kegiatan Parenting Islami di RA Milda Wiranti

\section{Pelaksanaan dan Revisi Modul Parenting Islami pada Uji Coba Lebih Luas}

Uji coba lapangan lebih luas dilakukan di RA An Nida selama 6 (enam) hari dengan model ceramah, bermain peran, tanya jawab, dan ditutup dengan tes. Kegiatan ini diikuti 9 (sembilan) orang tua murid. Dalam pelaksanaan kegiatan, peneliti memulai dengan memberikan pretes, penyampaian materi, bermain peran, tanya jawab, dan diakhiri dengan posttes. Modul yang digunakan adalah modul yang sudah diperbaiki dengan mengacak 8 (delapan) materi dari 41 materi yang tersisa.

Hasil evaluasi tentang nilai pengetahuan, sikap, dan keterampilan peserta serta partisipasi orang tua dalam kegiatan Parenting Islami di RA An Nida dapat dilihat pada Gambar 5.

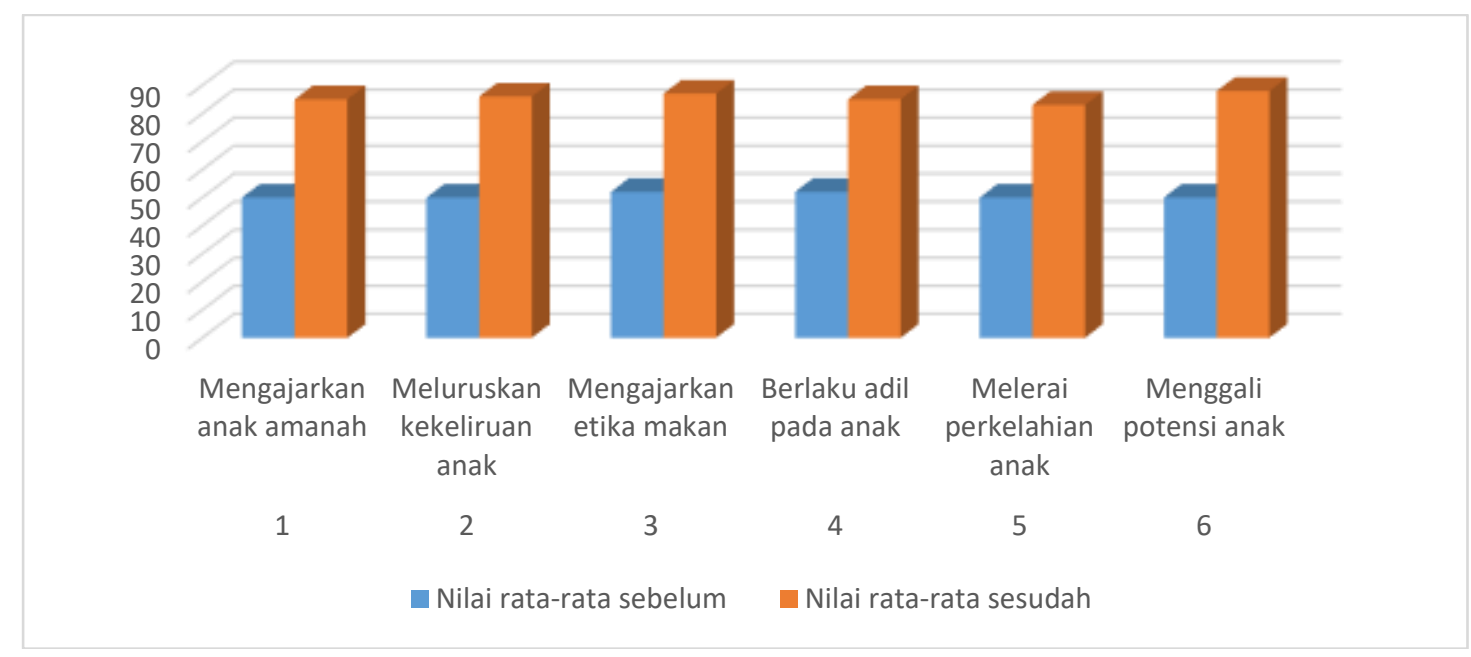

\section{Gambar 5. Peningkatan Nilai Rata-rata Pre tes dan Post tes Orang Tua RA An Nida}

Hasil pengamatan peneliti terhadap kehadiran, pemahaman materi, ketelibatan peserta dalam kegiatan Parenting Islami di RA An Nida dapat dilihat pada Gambar 6. Ratarata partisipasi kemudian diakumulasikan dan dihitung rata-rata akhirnya. Dari hasil 
perhitungan rata-rata akhir partisipasi orang tua diperoleh nilai 4,67 berkategori baik. Tingkat partisipasi orang tua dalam kegiatan Parenting Islami dapat dilihat pada Gambar 6.

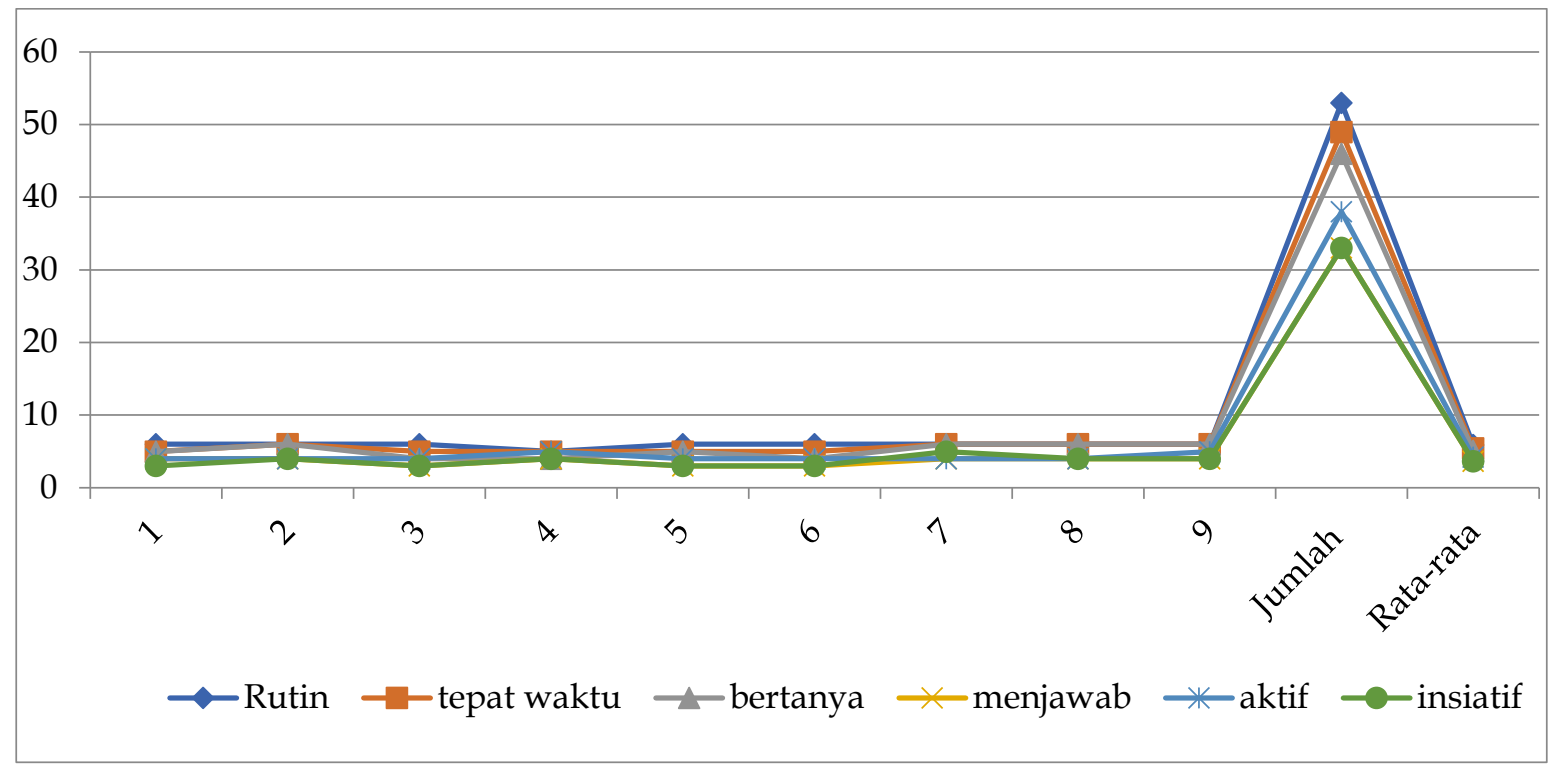

Gambar 6. Partsipasi Orang Tua Pada Kegiatan Parenting Islami di RA An Nida

Ujicoba di RA An Nida menunjukkan ada perbedaan nilai rata-rata antara sebelum dan sesudah kegiatan pembelajaran sebesar 34 poin, dimana nilai rata-rata sebelum pembelajaran 51 menjadi 85 setelah pembelajaran. Hasil uji statistik juga menunjukkan bahwa terjadi perbedaan nilai rata-rata yang signifikan yaitu $t_{\text {hitung }} 39,260$ dari $t_{\text {tabel }}$ sebesar 3,499 pada taraf kepercayaan 95\% dengan tingkat kesalahan 5\%.

Meskipun terjadi peningkatan yang lebih baik pada kemampuan orang tua dalam memahami, menunjukkan sikap, dan keterampilan mengasuh anak sesuai materi yang dibahas, namun peneliti mendapatkan saran dari pengelola Kelompok Kerja Orang Tua di RA An Nida untuk menambahkan kegiatan melibatkan anak dalam praktik bermain peran. Beberapa orang tua setuju untuk melakukan praktik nyata dengan anak daripada dilakukan dengan para peserta saja. Peneliti menambahkan saran tersebut di dalam modul bahwa sebaiknya bermain peran dilakukan dengan anak bukan dengan sesama orang tua.

\section{Pelaksanaan dan Revisi Modul Parenting Islami pada Uji Kelayakan}

Uji kelayakan dilakukan di TK IT Bunayya 7 yang merupakan lembaga PAUD yang memiliki karakteristik: Akreditasi A, orang tua siswa dengan pendidikan dan ekonomi menengah ke atas. Uji kelayakan dilakukan selama 6 (enam) hari dengan model ceramah, bermain peran ibu-anak, tanya jawab, dan ditutup dengan tes. Kegiatan ini diikuti 27 orang tua murid. Dalam pelaksanaan kegiatan, peneliti memulai dengan memberikan pretes, penyampaian materi, diskusi kasus, bermain peran, tanya jawab, dan diakhiri dengan posttes. Materi yang digunakan dalam uji kelayakan diambil secara acak dari 33 materi yang tersisa sebanyak 6 (enam) materi. Hasil evaluasi tentang nilai pengetahuan, sikap, dan keterampilan peserta serta partisipasi orang tua dalam kegiatan Parenting Islami di TK IT Bunayya 7 dapat dilihat pada Gambar 7.

Berdasarkan hasil pengamatan peneliti terhadap kehadiran, pemahaman materi, dan keterlibatan peserta dalam kegiatan Parenting Islami diperoleh data pada Gambar 8. Rata-rata partisipasi kemudian diakumulasikan dan dihitung rata-rata akhirnya. Dari hasil perhitungan rata-rata akhir partisipasi orang tua diperoleh nilai 4,75 berkategori baik. Tingkat partisipasi orang tua dalam kegiatan Parenting Islami dapat dilihat pada Gambar 8. 


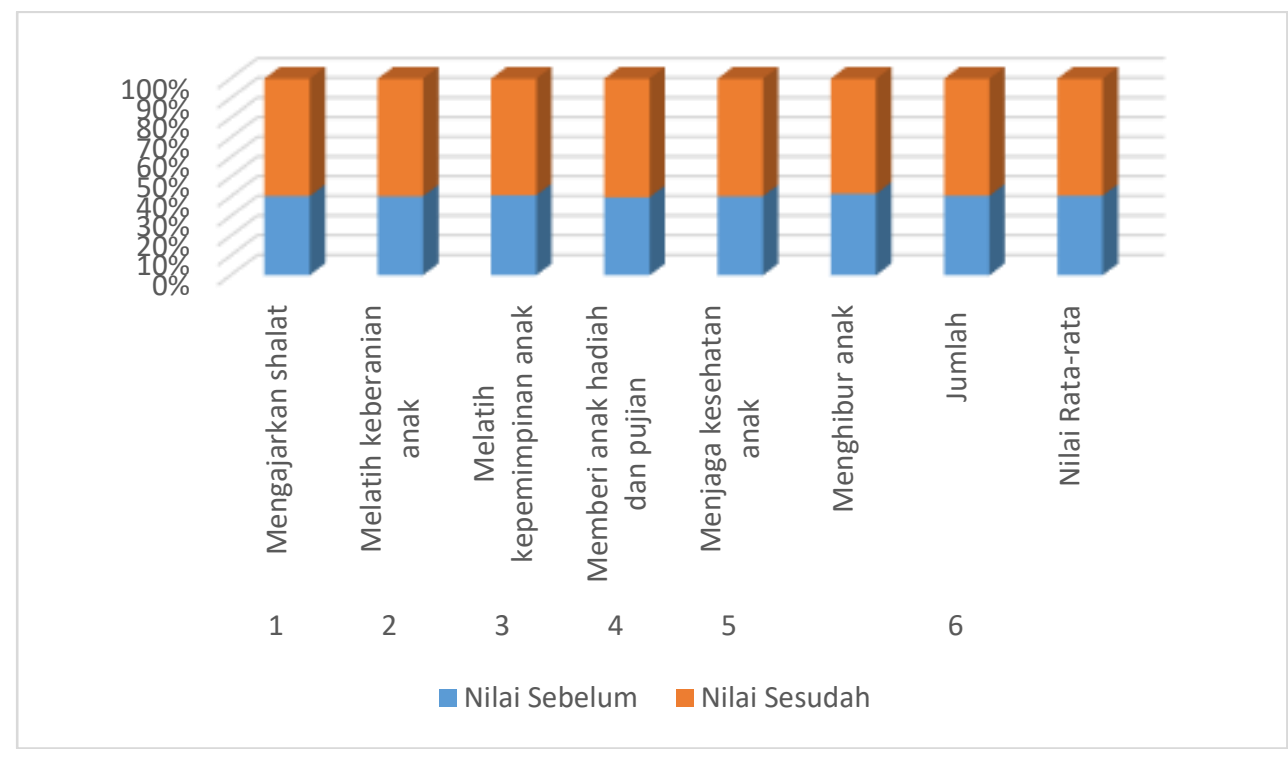

Gambar 7. Peningkatan Nilai Rata-rata Siswa TK IT Bunayya 7

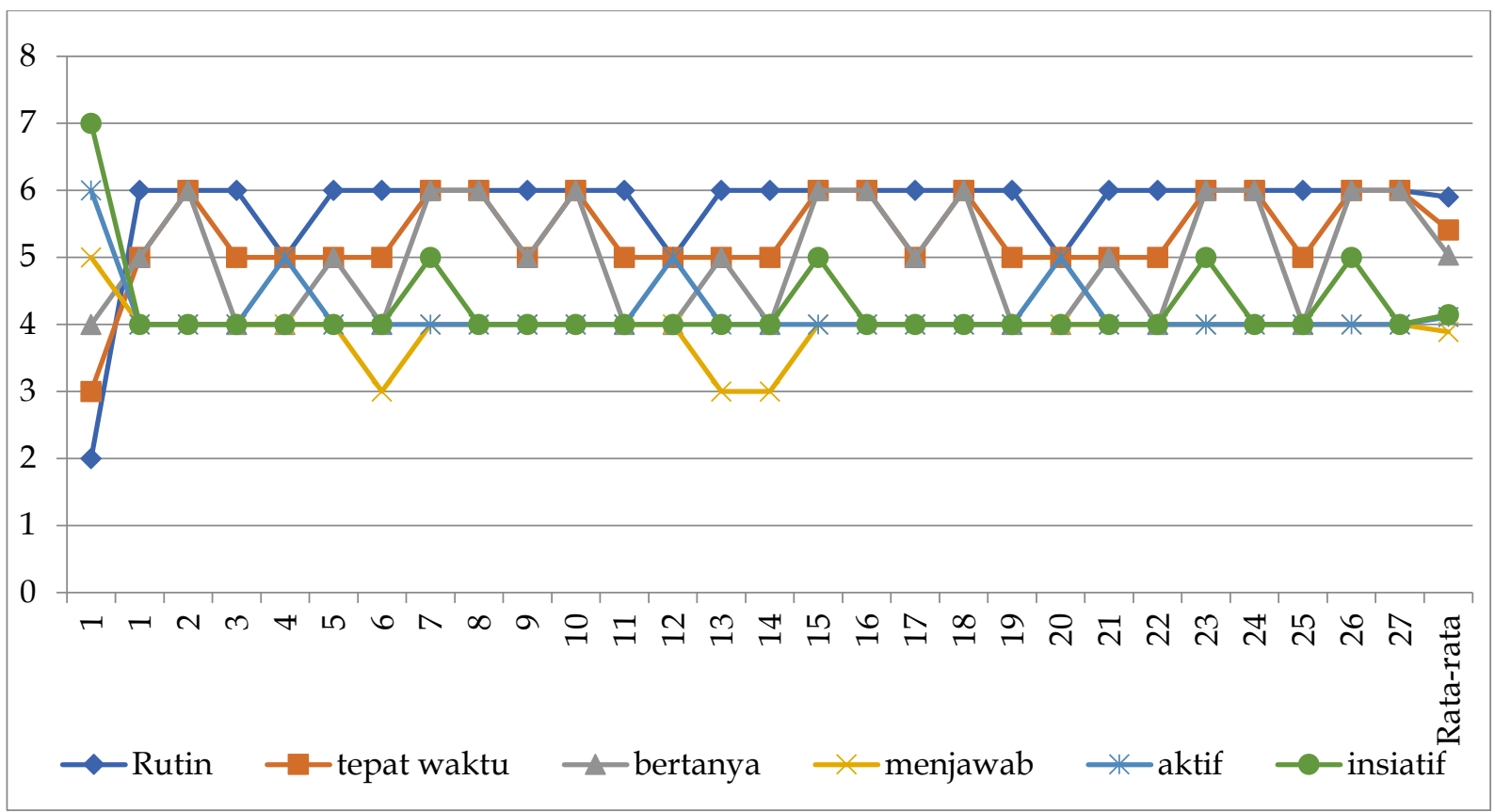

\section{Gambar 8. Partsipasi Orang Tua Pada Kegiatan Parenting Islami di TK IT Bunayya 7}

Ujicoba di TK IT Bunayya 7 juga menunjukkan ada perbedaan nilai rata-rata antara sebelum dan sesudah kegiatan pembelajaran sebesar 28,5 poin, dimana nilai rata-rata sebelum pembelajaran 60 menjadi 28,5 setelah pembelajaran. Hasil uji statistik juga menunjukkan bahwa terjadi perbedaan nilai rata-rata yang signifikan yaitu $t_{\text {hitung }} 50,246$ dari $t_{\text {tabel }}$ sebesar 4,032 pada taraf kepercayaan 95\% dengan tingkat kesalahan 5\%. Dari ketiga hasil evaluasi tersebut diperoleh informasi meskipun poin peningkatan lebih kecil di TK IT Bunayya 7 namun secara statistik kegiatan Parenting Islami lebih tangguh meningkatkan pengetahuan orang tua pada kelompok ini. Sebab mereka telah memiliki kemampuan yang lebih baik dari 2 (dua) sekolah sebelumnya. Namun peningkatan pengetahuan setelah menggunakan panduan orang ini sangat baik dan tinggi.

Di dalam uji kelayakan peneliti masih mendapatkan saran dari orang tua dan pengelola pendidikan untuk menambahkan tatacara penggunaan modul yaitu dengan 
melibatkan orang tua secara bergantian menjadi pembicara dengan berpedoman pada materi yang ada dalam modul. Mereka menyarankan jika orang tua menjadi pembicara maka ada 2 (dua) keuntungan dari modul ini: pertama, secara materi menghemat dana kegiatan parenting dan kedua memberi kesan yang lebih kuat bagi orang sebab jika mereka mengajarkannya kepada orang tua lainnya mereka menjadi lebih paham terhadap materi yang disampaikannya Peneliti sepakat memasukkan ke dalam panduan kegiatan penggunaan modul Parenting Islami di Lembaga Pendidikan Anak Usia Dini.

\section{Kegiatan Diseminasi dan Sosialisasi Modul Parenting Islam di Lembaga PAUD}

Kegiatan diseminasi dan sosialisai produk akhir dilakukan dengan cara menerbitkan Modul Parenting Islami di lembaga PAUD ber-ISBN pada penerbit yang menjadi anggota IKAPI . Modul tersebut dibagikan kepada 20 lembaga PAUD yang berada di wilayah Kabupaten Deli Serdang dan Kota Medan. Modul juga disumbangkan ke perpustakaan Universitas Islam Negeri Sumatera Utara Medan agar penelitian ini juga memberikan kontribusi wawasan kepada sivitas akademika yang sedang mempelajari atau melakukan penelitian dengan objek yang relevan. Modul dalam bentuk e-book dibagikan peneliti pada researchgate.net.

\section{Pembahasan}

Orang tua tidak dilahirkan sebagai pendidik yang baik. Untuk dapat mendidik anakanaknya dengan baik orang tua harus belajar. Pembelajaran dapat dilakukan orang tua secara mandiri atau bersama-sama. Santrock (Santrock, 2009) menyatakan kemampuan mengasuh bagi orang tua sangat penting, namun hanya sedikit sekali lembaga yang peduli terhadap hal ini, termasuk para orang tua. Islam menegaskan bahwa orang tua bertanggung jawab terhadap pengasuhan dan pendidikan anak, terutama menyelamatkan anak-anaknya dari api neraka. (Suwaid, 2018) menyatakan anak-anak memiliki banyak misteri, maka dibutuhkan pengetahuan yang luas untuk memahami misteri tersebut. Salah satu cara yang dapat dilakukan orang tua untuk memahami misteri anak dengan belajar bagaimana Rasulullah mendidik anak melalui tafsir alquran dan hadis Rasulullah. Penelitian Nurpitasari et al. (2018) menunjukkan bahwa orang tua yang aktif dalam kegiatan parenting mendapatkan manfaat penambahan pengetahuan orangtua dalam mengasuh anak, meningkatkan perkembangan anak yaitu anak lebih percaya diri, dan prestasi dari sekolah. Penelitian Faizah (2018) juga menemukan bahwa Implementasi Parenting Class di PAUD Wafdaa Kids Center menunjang pendidikan akhlak yang mencakup sikap menjalankan amanah dengan sebaik mungkin, berperilaku sopan santun terhadap siapapun, menggunakan waktu yang ada untuk kegiatan yang produktif dan bermanfaat, berkata jujur walaupun dikeadaan yang menyakitkan hati, dan bersikap saling mengasihi terhadap sesama makhluk hidup pada orang tua yang mengikuti kegiatan parenting.

Penerapan pola asuh orang tua (Parenting) pada perkembangan anak usia dini menurut sudut pandang islam haruslah dapat memberikan penjelasan bahwa sebenarnya semua anak itu terlahir dalam keadaan fitrah, menanamkan tauhid dan aqidah yang benar kepada anak, mengajari anak untuk mengerjakan shalat, mengajari anak untuk membaca $\mathrm{Al}$ Quran, memotivasi anak untuk selalu berdoa, mengajarkan anak untuk selalu bersyukur, memotivasi anak untuk beribadah di masjid, mengajari anak untuk selalu menjaga aurat, mengajari anak untuk selalu menjaga kebersihan tubuh, dan mengajari anak untuk saling menyayangi sesama mahluk ciptaan Allah. (Erica, 2016)

Penelitian ini menunjukkan bahwa kehadiran dan pengetahuan orang tua lebih meningkatkan setelah mengikuti kegiatan parenting, sebab materi yang dibahas sesuai dengan kebutuhan orang tua dan orang tua berkesempatan secara bergantian sebagai narasumber. Model pembelajaran ini sesuai dengan saran ahli tentang pembelajaran orang dewasa dimana partisipasi dan interaksi merupakan bagian yang penting dalam pembelajaran Gitterman (2004). Pemberian kesempatan interaksi antara fasiltator dan peserta pelatihan kegiatan Bina Keluarga di Kelurahan Kebon Jayanti telah berhasil meningkatkan kesadaran masyarakat 
tentang pentingnya peningkatan kesejahteraan keluarga (Muslikhah et al., 2018). Menurut Ningsih et al (2018) tujuan utama pentingnya parenting dilakukan adalah untuk memberikan pemahaman dan pengetahuan kepada orangtua tentang pertumbuhan dan perkembangan anak. Dengan demikian dibutuhkan fasilita yang mendukung agar tujuan tersebut dicapai seperti penggunaan buku panduan model alternatif parenting Islami yang telah dikembangkan pada penelitian ini. Peserta kegiatan sepakat bahwa pengasuh anak harus terus menerus menambah pengetahuannya dalam mendidik anak sebab mereka mendidik anak yang berbeda dengan jaman yang telah dilaluinya.

Allah swt berfirman dalam Q.S at-Taghabun ayat 14 yang menurut (Shihab, 2012) artinya: wahai orang-orang yang beriman! Sesungguhnya di antara istri- istrimu dan anakanakmu ada yang menjadi musuh bagimu, maka berhati-hatilah kamu terhadap mereka dan jika kamu memaafkan dan kamu santuni serta mengampuni(mereka), maka sungguh, Allah Maha Pengampun lagi Maha Penyayang. Penelitian Fuadi et al. (2020) membahas mengenai kandungan surat al-Taghabun ayat 14-15 yang menyatakan bahwa firman Allah swt tersebut mengatur secara normatif peran keluarga untuk dapat merasakan kehadiran dan pengawasan Allah swt. dimana saja dan kapan saja, sehingga menimbulkan efek positif seperti kemampuan anak untuk bersikap jujur, amanah, istiqomah, bertulus ikhlas, bersyukur kepada Allah, dan malu melakukan perbuatan tercela.

Banyak kasus yang dapat dijadikan contoh bahwa atau anak-anak yang tidak dididik dengan baik oleh orang tuanya dapat menyebabkan kesengsaraan dalam kehidupan orang tua. Oleh sebab itu orang tua harus belajar ilmu mendidik anak dan melaksanakan pendidikan yang baik pada anak-anaknya. Orang tua tidak boleh menyerahkan segala usaha pendidikan anak ke sekolah, meskipun orang tua telah memilihkan sekolah terbaik untuk anak-anaknya. Setelah melakukan pendidikan yang baik pada anak-anaknya, orang tua juga harus meniru cara Nabi Ibrahim dalam mengukuhkan iman keturunannya. Orang tua perlu membaca doa yang dibacakan Nabi Ibrahim dalam Q.S al-Baqarah ayat 128 yang artinya di dalam Al-Jawi (2016) yaitu: Ya Tuhanku jadikanlah negeri Mekkah ini negeri yang aman dan berilah rezeki berupa buah-buahan kepada penduduknya yaitu di antara mereka yang beriman kepada Allah dan hari kemudian.

Menurut Gottlieb (1995) hidup dengan anak berusia tiga tahun adalah petualangan yang luar biasa. Anak membawa sudut pandang unik yang menyegarkan hubungan dengan fenomena alam dan situasi sehari-hari. Melihat dunia melalui mata anak berusia tiga tahun itu lucu, mengejutkan, dan memperkaya pengetahuan. Oleh sebab itu orang tua harus belajar mengenali seorang anak berusia tiga tahun agar dapat membina hubungan baik dengan anaknya. Manap \& Baba (2016) menyatakan bahwa kemahiran mendidik anak sangat perlu dikuasai setiap orang tua. Oleh sebab itu kajian pengasuhan anak harus dikembangkan untuk membantu orang tua dalam mendidik perilaku anak-anaknya. Salah satu kemahiran mendidik anak dapat dijadikan pola adalah kemahiran mendidik anak dari Imam al-Ghazali yang menyatakan ada 4 (empat) pola mendidik anak yaitu: memiliki ilmu, hubungan orang tua dengan Allah, hubungan orang tua dengan anak dan hubungan orang tua dengan masyarakat.

Menurut Baswedan (2016) profesi menjadi orang tua adalah profesi yang paling tidak dipersiapkan. Maknanya orang tua harus belajar menjadi orang tua agar dapat melaksanakan profesinya menjadi orang tua. Ariyati (Ariyati, 2016) menambahkan bahwa tidak jarang orangtua melakukan kesalahan dan berdampak buruk bagi anak. Penyebabnya, kekurangpahaman orangtua, serta kurangnya pengetahuan mengenai pola asuh orang tua yang sangat berperan bagi anak usia dini. Hal ini juga dijelaskan Raraswati (2016) bahwa orang tua perlu belajar melakukan pengasuhan positif yang dilakukan dengan berdasarkan kasih sayang, saling menghargai, membina hubungan hangat dengan anak, dan menstimulasi tumbuh kembang anak. Pendekatan yang menggunakan penghargaan dan perlindungan, dan mengedepankan kebutuhan anak akan menjadikan pendidikan dan pengasuhan mencapai hasil yang optimal. 
Pentingnya pendidikan orang tua juga dijelaskan oleh Ismaniar \& Sunarti (2018) bahwa cara terbaik untuk meningkatkan pengetahuan dan keterampilan orang tua dalam mendidik mendidik adalah dengan mengikuti program parenting. Program parenting akan menjadi lebih efektif jika menggunakan buku panduan. Haniah et al. (2012) menyatakan bahwa anak dalam al-Qur'an dijelaskan Allah sebaga perhiasan, musuh, fitnah, ujian, dan penyejuk mata. Oleh sebab itu, orang tua harus mendidik anak dengan baik agar anak tidak menjadi fitnah, musuh atau ujian. Untuk merealisasikan pendidikan yang baik, maka orang tua harus dapat menjadi orang yang shalih dan bisa menunjukkan qudwah (keteladanan) bagi anak-anak. Orang tua menjadi teladan jika dia memiliki ilmu agama dan mempraktikkannya dalam kehidupan sehari-hari.

Di dalam penelitian ini orang tua telah menjadi narasumber bagi orang tua lain untuk materi yang dipilihnya dari buku panduan yang telah disediakan. Menjadi pengajar merupakan kegiatan belajar tertinggi, sebab dengan mengajarkan sesuatu kepada orang lain menjadikan yang bersangkutan lebih menguasai materi (Guskey, 1980). Orang tua juga dapat berlatih memerankan cerita terkait materi di dalam buku panduan dengan temannya sehingga mereka mengalami secara langsung cara mengajarkan materi tersebut kepada anak melalui kegiatan bermain peran. Penelitian Siska (2011) dan Chrismayanti et al. (2016) mempunyai hasil yang sependapat bahwa metode bermain peran cocok diterapkan untuk anak dan hasil penerapannya dapat menjadi bukti perubahan perilaku anak. Menurut Ainiyah (2017) Sebagai makhluk sosial, manusia mengamati perilaku orang lain. Dari hasil penelitian Mukid (2009), Kurniyati (2016) dan Widyanti (2019) dapat disimpulkan bahwa bermain peran (role playing) dapat mengembangkan pengetahuan anak tentang dunia disekitarnya, seperti pengetahuan bahasa, cara mengambil sudut pandang, rasa empati, mengasah imajinasi, dan pembentukan sikap.

Partisipan penelitian mengakui kedua cara dalam menggunakan buku panduan orang tua dalam kegiatan parenting di sekolah telah membekali mereka pengetahuan, sikap, dan keterampilan sehingga mereka dapat menjadi dari materi-materi dalam buku tersebut untuk anak-anaknya. Orang tua menjadi model bagi anak merupakan sebuah keniscayaan sebab orang tua adalah orang yang paling selalu bersama dengan anak. Santrock (Santrock, 2009) menyatakan bahwa tempramen anak-anak dipengaruhi pola asuh orang tuanya. Menurut Setiardi (2017) Anak-anak yang mandiri bisa diasuh dengan kasih sayang dan ketegasan, sedangkan anak-anak yang penakut diasuh dengan kekerasan, dan anak-anak yang labil diasuh dengan kemanjaan, dan anak-anak menarik diri diasuh dengan ketidakpedulian. Islam juga mengajarkan orang tua harus menjadi model yang ideal bagi anak-anaknya. Anak-anak dilahirkan sebagai peniru yang ulung, mereka meniru perilaku/moral dengan sangat cepat dan persis mengalahkan hasil copy mesih foto copy tercanggih. Mereka meniru untuk mendapatkan kasih sayang dan pengakuan dari orang-orang yang ditirunya (Kohlberg \& Hersh, 1977).

Penelitian ini telah menghasilkan buku panduan parenting Islami yang berisi materimateri pendidikan Islam yang dapat digunakan orang tua sebagai alternatif dalam mendidik anak. Buku model alternatif parenting Islami ini dapat digunakan dengan metode bermain peran dalam kehidupan sehari-hari di rumah. Menurut Suwartini (2016) faktor imitasi dari lingkungan (belajar sosial) juga sangat berpengarh terhadap cara ia mempersepsi diri dan berperilaku. Menurut Lesilolo (2018) teori Bandura menekankan tentang pentingnya peserta didik mengolah sendiri pengetahuan atau informasi yang diperoleh dari pengamatan model di sekitar lingkungan. Model yang dapat ditiru, paling nyata dan dekat dengan anak adalah orang tuanya. Orang tua juga dapat menjadi narasumber untuk materi-materi parenting dalam pertemuan parenting di sekolah. Para peserta mengaku bahwa selama ini mereka mengikuti kegiatan parenting di sekolah karena kewajiban, tetapi hal tersebut berubah setelah adanya buku panduan ini yang menjadikan tujuan orang tua mengikuti kegiatan parenting karena ingin menambah pengetahuan, membentuk sikap, dan melatih keterampilan anaknya. Hal itu juga diakui oleh kepala sekolah dan guru bahwa jumlah peserta kegiatan parenting semakin 
meningkat dan dihadiri langsung oleh orang tua (ayah/ibu) bukan wali siswa. Temuan penelitian ini sejalan dengan teori pendidikan orang dewasa yang menyatakan keterlibatan peserta merupakan kunci keberhasilan dalam sebuah program pendidikan (Gitterman, 2004).

Dengan demikian, model alternatif parenting Islami pada lembaga pendidikan anak usia dini yang produknya berbentuk buku terbukti layak digunakan untuk orang tua dan siswa di lembaga PAUD, dan buku ini juga terbukti dapat dijadikan sebagai alternatif panduan untuk mensukseskan kegiatan parenting Islami di lembaga pendidikan anak usia dini. Bahkan orang tua dapat menggunakan panduan ini sebagai materi parenting di sekolah dan kegiatan mendidik anak di rumah. Di sekolah, orang tua dapat menjadi narasumber dan melakukan praktik dengan menggunakan materi-materi pendidikan anak yang ada dalam buku. Di rumah orang tua dapat mendidik anak dengan melakukan kegiatan bermain peran bersama anak, sebab penanaman nilai-nilai agama dan akhlak mulia sangat cocok dilakukan dengan bermain peran. Dengan bermain peran, orang tua membentuk pemahaman dan pembiasaan perilaku yang dapat diperankan anak dalam kehidupan sehari-hari.

\section{SIMPULAN}

Penelitian ini telah mengembangkan model alternatif parenting Islami untuk lembaga PAUD, khususnya PAUD berbasis Islam seperti RA dan TK IT. Hal tersebut karena buku panduan model alternatif parenting yang dikembangkan berasaskan ajaran Islam sehingga beragama Islam menjadi salah satu karakteristik pemilihan subyek pada penelitian ini. Buku panduan parenting Islami yang dikembangkan terlah terbukti valid dan mempunyai beberapa keunikan dibandingkan dengan buku parenting lain, diantaranya yaitu: materi parenting berlandaskan alquran dan hadis dipilih peserta sesuai dengan kebutuhannya, ilustrasi gambar menarik, terdapat dialog pada naskah dan gambar seperti komik, serta terdapat tugas orang tua untuk mengukur pencapaian parenting Islami.

\section{UCAPAN TERIMA KASIH}

Ucapan terima kasih disampaikan kepada semua pihak yang sudah membantu dan memfasilitasi penelitian. Secara khusus, ucapan terima kasih disampaikan kepada kepala sekolah, guru, siswa dan orang tua siswa di RA Milda Wiranti, RA An Nida, TK IT Bunayya 7 karena sudah memberikan izin serta ikut berpartisipasi di dalam proses penelitian. Ucapan terima kasih juga disampaikan kepada DIPA Direktorat Jenderal Pendidikan Islam dan tim dari LP2M UIN Sumatera Utara Medan karena telah memfasilitasi penelitian dan penulisan artikel.

\section{DAFTAR PUSTAKA}

Ainiyah, Q. (2017). Social Learning Theori dan Perilaku Agresif Anak dalam Keluarga. AlAhkam: Jurnal Ilmu Syari'ah Dan Hukum, 2(1), 91-104. https://doi.org/10.22515/alahkam.v2i1.789

Al-Jawi, A.-A. A.-S. M. N. (2016). Tafsir Al-Munir Jilid 6. Bandung: Sinar Baru.

Annisa, Y. N. (2016). Home-Start Parenting Program untuk Meningkatkan Fungsi Emosi Ibu dalam Pengasuhan Anak Usia Dini. PSYMPATHIC: Jurnal Ilmiah Psikologi, 3(1). https://doi.org/10.15575/psy.v3i1.1096

Ariyati, T. (2016). Parenting di PAUD sebagai Upaya Pendukung Tumbuh Kembang Anak Usia Dini. Khazanah Pendidikan: Jurnal Ilmiah Kependidikan, 9(2). https:// doi.org/10.30595/jkp.v9i2.1065

Baswedan, A. R. (2016). Guru Mulia Karena Karya. Jakarta: Kementerian Pendidikan dan Kebudayaan.

Cathy, \& Bennett. (2013). Group-Based Parenting Program For Improving Dan Psychosocial Functioning: A Systematic Review. Journal of the Society for Social Work and Research, 4(4). https://doi.org/10.5243/jsswr.2013.20 
Chrismayanti, P. A. R., Tegeh, I. M., \& Tirtayani, L. A. (2016). Penerapan Metode Bermain Peran Untuk Meningkatkan Perilaku Kedisiplinan Pada Anak Usia 5-6 Tahun di PAUD Pradnya Paramita. Jurnal Pendidikan Anak Usia Dini Undiksha, 4(3). https:// doi.org/10.23887/paud.v4i3.8770

Erica, D. (2016). Penerapan Parenting Pada Perkembangan Anak Usia Dini Menurut Sudut Pandang Islam. Cakrawala: Jurnal Humaniora Universitas Bina Sarana Informatika, 16(2). https:// doi.org/10.31294/jc.v16i2.1286

Faizah, S. N. (2018). Implementasi Parenting Class Dalam Menunjang Pendidikan Akhlak di PAUD Wafdaa Kids Center Kecamatan Pringapus Kabupaten Semarang Tahun Pelajaran 2017/2018. IAIN Salatiga.

Fuadi, S. I., Antika, R., \& Rofiudin, N. (2020). Nilai-Nilai Pendidikan Akhlak dalam Keluarga: Kajian QS. al-Taghabun ayat 14-15. Matan: Journal of Islam and Muslim Society, 2(1). https:// doi.org/10.20884/1.matan.2020.2.1.2256

Gitterman, A. (2004). Interactive Andragogy. Journal of Teaching in Social Work, 24(3-4), 95112. https://doi.org/10.1300/J067v24n03_07

Gottlieb, S. E. (1995). Keys to Parenting Your Three Year Old. New York: Barron's Educational Series, Inc.

Grindal. (2016). The added impact of parenting education in early childhood education programs: A meta-analysis. Https://Www.Sciencedirect.Com/Science/Journal/01907409, Volume 70, 238-249. https:// doi.org/10.1016/j.childyouth.2016.09.018

Guskey, T. R. (1980). Mastery learning: Applying the theory. Theory Into Practice, 19(2), 104111. https://doi.org/10.1080/00405848009542882

Haniah, Ikhwan, W. K., Fatmawati, I., Nurul, F., \& Sulaiman. (2012). Bahasa Indonesia Kontekstual. Surabaya: Pustaka Radja.

Hasibuan, H. B., Nasution, Z., \& Zannah, M. (2021). Meningkatkan Penguasaan Kosa Kata Bahasa Inggris Menggunakan Media Audio Visual Pada Anak Usia 5-6 Tahun di RA Babussalam. Jurnal Raudhah, 9(1). https://doi.org/10.30829/raudhah.v9i1.943

Ismaniar, \& Sunarti, V. (2018). Buku Ajar Pelatihan Parenting. Universitas Negeri Padang. https:// doi.org/10.31227/osf.io/c62sw

Kenkre, J., \& Young, E. (2013). Home Start Support and Friendship For Families. Building Resilience: Volunteer Support for Families with Complex Circumstances And Needs.

Kohlberg, L., \& Hersh, R. H. (1977). Moral development: A review of the theory. Theory Into Practice, 16(2), 53-59. https:// doi.org/10.1080/00405847709542675

Kurniyati, E., Sutarjo, A., \& Wulan, N. S. (2016). Peranan Metode Bermain Peran (Role Playing) dalam Keterampilan Berbicara Anak Usia Dini. Jurnal Infantia (PGPAUD Serang), 4(2).

Lesilolo, H. J. (2018). Penerapan Teori Belajar Sosial Albert Bandura dalam Proses Belajar Mengajar di Sekolah. KENOSIS: Jurnal Kajian Teologi, 4(2), 186-202. https:// doi.org/10.37196/kenosis.v4i2.67

Manap, J., \& Baba, S. (2016). Al-Ghazali's Parenting Skills Attributes Model (Model Atribut Kemahiran Keibubapaan Al-Ghazali. Jurnal Hadhari, 8(1).

Miller, S., \& Sambell, K. (2003). What do Parents Feel they Need? Implications of Parents' Perspectives for the Facilitation of Parenting Programmes. Children and Society, 17(1), 32-44. https://doi.org/10.1002/chi.726

Muji, M. (2014). Pengembangan Perangkat Pembelajaran Keterampilan Membaca Model Pembelajaran Kontekstual. Pancaran Pendidikan, 3(4), 1-14.

Mukid, A. (2009). Self-Efficacy: Perspektif Teori Kognitif Sosial dan Implikasinya terhadap Pendidikan. Tadris: Jurnal Pendidikan Islam, 4(1). https:// doi.org/10.19105/tjpi.v4i1.247

Muslikhah, M.-, Kamil, M., \& Kamarubiani, N. (2018). The Implementation of Adult Learning Assumption Readiness Relationships in Improving the Effectiveness of Learning 
DOI: 10.31004/obsesi.v6i2.1149

Process. Journal of Nonformal Education, 4(2), 141-150. https://doi.org/10.15294/jne.v4i2.15995

Ningsih, F. D., Nasirun, M., \& Yulidesni. (2018). Pelaksanaan Program Parenting di Lembaga PAUD Kecamatan Basa Ampek. Jurnal Ilmiah Potensia, 3(1), 44-49. https:// doi.org/10.33369/jip.3.2.99-104

Nurpitasari, D. W., Wahyuni, S., \& Widianto, E. (2018). Parenting Day Sebagai Aktivitas Peningkatan Hubungan Orangtua Dan Anak. Jurnal Pendidikan Nonformal, 13(1). https://doi.org/10.17977/um041v13i1p1\%20-\%209

Raraswati, P. (2016). Seri Pendidikan Orang Tua: Pengasuhan Positif. Jakarta: Kementerian Pendidikan dan Kebudayaan.

Robbiyah, Ekasari, D., \& Witarsa, R. (2018). Pengaruh Pola Asuh Ibu terhadap Kecerdasan Sosial Anak Usia Dini di TK Kenanga Kabupaten Bandung Barat. Jurnal Obsesi: Jurnal Pendidikan Anak Usia Dini, 2(1). https://doi.org/10.31004/obsesi.v2i1.10

Santrock, J. W. (2009). Psikologi Pendidikan (Education Psychology) (D. Angelica (ed.)). Jakarta: Salemba.

Setiardi, D. (2017). Keluarga Sebagai Sumber Pendidikan Karakter Bagi Anak. Tarbawi : Jurnal Pendidikan Islam, 14(2). https:// doi.org/10.34001/tarbawi.v14i2.619

Shihab, M. Q. (2012). Tafsir Al Lubab Jilid 3. Tangerang: Lentera Hati.

Siska, Y. (2011). Penerapan Metode Bermain Peran (role Playing) dalam Meningkatkan Keterampilan Sosial dan Keterampilan Berbicara Anak Usia Dini. PORTAL JURNAL: Universitas, Edisi Khus(2).

Sugiyono. (2017). Metode Penelitian Pendidikan Pendekatan Kuantitatif, Kualitattif dan RnD. Bandung: Alfabeta.

Suwaid, M. N. A. H. (2018). Prophetic Parenting. Jakarta: Pro U Media-Pustaka Aysha.

Suwartini, S. (2016). Teori Kepribadian Social Cognitive: Kajian Pemikiran Albert Bandura Personality Thery Social Cognitive: Albert Bandura. Al-Tazkiah: Jurnal Bimbingan Dan Konseling Islam, 5(1). https:/ / doi.org/10.20414/altazkiah.v5i1.1325

Widyanti, A., Dharsana, I. K., \& Suarni, N. K. (2019). Efektivitas Konseling Kognitif Sosial Teknik Bermain Peran untuk Meningkatkan Self Afiliasi. Jurnal Ilmiah Bimbingan Konseling Undiksha, 10(2), 73-81. https:// doi.org/10.23887/jibk.v10i2.23284 